\title{
The three-dimensional lithospheric structure of the Falkland Plateau region based on gravity modelling
}

\author{
GEOFFREY S KIMBELL ${ }^{1} \&$ PHILIP C RICHARDS ${ }^{2}$ \\ ${ }^{1}$ British Geological Survey, Keyworth, Nottingham NG12 5GG, UK (e-mail:gsk@bgs.ac.uk) \\ ${ }^{2}$ British Geological Survey, West Mains Road, Edinburgh EH9 3LA, UK
}

\begin{abstract}
The lithospheric structure of the Falkland Plateau region has been modelled by making an initial estimate on the basis of local isostasy and then refining the geometries by inversion of gravity anomalies. The model predicts a crustal thickness beneath the Falkland Plateau Basin that is more than twice that previously inferred from seismic evidence. The preferred explanation is that the seismic survey detected high-velocity (?underplated) lower crust rather than upper mantle. This is compatible with the results of deep seismic experiments over the conjugate Filchner Block of Antarctica and also appears likely on the basis of the position of the Falkland Plateau Basin in relation to the Karoo-Ferrar magmatic province at the time of extension. Continental crust is inferred to be continuous beneath the northern part of the Falkland Plateau, as there are consistent magnetic and flexural anomalies associated with the continent-ocean boundary. Flexural modelling of the southern margin of the plateau indicates lateral variations in strength, with the strongest lithosphere beneath the Falkland Plateau Basin. This may indicate thick oceanic crust beneath the southern part of the basin or the effect of thinning relatively weak continental crust and replacing it with relatively strong underplating.
\end{abstract}

[End of Abstract]

The Falkland Plateau is a rectilinear bathymetric feature in the South Atlantic Ocean which extends eastward from the South American continental shelf (Fig. 1a). A transform margin along its northern side accommodated a $1400 \mathrm{~km}$ offset between the continent-ocean boundary on the Argentine shelf and that to the east of Maurice Ewing Bank during the opening of this ocean, which commenced at about 130 Ma (Fig. 1b). Antarctica rifted away from the southern side of the Falkland Plateau at about $145 \mathrm{Ma}$ (Jokat et al. 2003), and the Scotia Sea has developed on this side of the plateau in the last $30 \mathrm{Ma}$ as a result of extension behind an eastward-migrating subduction zone. Burdwood Bank and the North Scotia Ridge are continental fragments along the northern edge of the Scotia Plate, which is converging obliquely (in a sinistral sense) with the South American Plate and overriding it such that the southern edge of the Falkland Plateau has flexed downward to form the Falkland Trough (Bry et al. 2004).

Onshore paleomagnetic (Taylor \& Shaw 1989), stratigraphic (Marshall, 1994; Trewin et al. 2002) and structural (Curtis \& Hyam 1998) observations suggest that the Falkland Islands rotated through up to $180^{\circ}$ in a clockwise direction during the break-up of Gondwana, from an original position adjacent to the east coast of Southern Africa. After allowing for subsequent relative plate motion, clockwise tectonic rotation of a Falkland Islands microplate through about $120^{\circ}$ is implied. There is, however, little evidence for rotation and docking in the sedimentary sequences imaged in the offshore area (Richards et al. 1996). If the Falkland Plateau is composed of rotated Gondwanan fragments, then these must have been assembled 
after the intrusion of the Early Jurassic dykes on the Falkland Islands (which provide the key palaeomagnetic evidence for such rotation) and before the deposition of the major sedimentary sequences in the offshore basins. Storey et al. (1999) argue that rotation was rapid, commencing at the time of Karoo-Ferrar magmatism at c. $183 \mathrm{Ma}$ and complete by about $175 \mathrm{Ma}$. They suggest that it was facilitated by doming and the development of a viscously deforming substratum above the mantle plume responsible for this magmatism.

Evidence regarding the deep structure of the Falkland Plateau is limited, but the prevalent view has been that its central part is underlain by normal thickness oceanic crust (Ludwig 1983; Barker 1999). In this paper we present the results of three-dimensional modelling based on gravity data (Fig. 1c) that challenge this view. We propose that there is a much greater crustal thickness beneath the plateau and that this reflects the influence of Karoo-Ferrar magmatism on its evolution.

\section{Sedimentary cover}

Figure $2 \mathrm{a}$ is a map of sedimentary thickness that has been compiled from a variety of sources. Much of the information comes from a series of seismic cruises conducted by the LamontDoherty Geological Observatory in the 1960s and 1970s. These included seismic refraction (airgun-sonobuoy) experiments and single- and multi-channel seismic reflection profiling. Profiles 139 to 145 (labelled in Fig. 1 and superimposed on subsequent figures) are particularly valuable in providing both multichannel reflection images of the sedimentary cover (Lorenzo \& Mutter 1988) and insights from refraction measurements into the velocity structure of the basins and underlying basement (Ludwig 1983). Such data have previously been incorporated in sediment thickness maps (e.g. Divins \& Rabinowitz 1990) which have been compiled and digitised by the US National Geophysical Data Centre (http://www.ngdc.noaa.gov/mgg/sedthick/sedthick.html). Additional sources employed in Fig. 2a included Lorenzo \& Mutter (1988), Turic et al. (1980) and Bry et al. (2004).

There are four main basins around the Falkland Islands: the Falkland Plateau Basin, South Falkland Basin, Malvinas Basin and North Falkland Basin (Fig. 2a; Richards et al. 1996). These are inferred to have been initiated by Early to Mid Jurassic rifting associated with the break-up of Gondwana. Lorenzo \& Mutter (1988) estimated that extension took place within the Falkland Plateau Basin during the Mid Jurassic to Early Cretaceous, whereas Marshall (1994) placed the main extensional phase in the Early Jurassic. Richards et al. (1996) noted that the major extensional faults appear to terminate upwards at about top Jurassic level and raised the possibility that extension occurred as early as the Permo-Triassic. The Falkland Plateau Basin contains a large thickness of sedimentary rocks, probably exceeding $10 \mathrm{~km}$ on its western side (Fig. 2; Richards et al. 1996; Bry et al. 2004).

\section{Basement}

Direct evidence for the continental nature of Maurice Ewing Bank is provided by the metamorphic basement drilled at DSDP Site 330 (Fig. 1; Barker et al. 1976). These rocks have not been accurately dated, but the lithologies (gneiss, granitoids) and isotopic compositions are similar to those found in the Mesoproterozoic (c. 1.1 Ga) Cape Meredith Complex, which is exposed on the southern tip of West Falkland (Wareham et al. 1998; Jacobs et al. 1999; Thomas et al. 2000). They were formed within a Grenville-age juvenile island arc which extended from southern Africa through the Falkland region and into East Antarctica (Wareham et al. 1998; Thomas et al. 2000). Gneissic continental basement rocks have also been found in dredge hauls along the top of the Falkland Escarpment, although such hauls also include basaltic rocks (Lorenzo \& Mutter 1988; Lorenzo \& Wessel 1997). Further evidence for the continental nature of the basement immediately south of the 
Falkland Escarpment comes from seismic imaging of tilted fault blocks in this region (Lorenzo \& Mutter 1988; Barker 1999) and from the fact that a well-defined magnetic anomaly just to the north of the escarpment is indicative of the contrast between magnetic, oceanic basement to the north and less magnetic, continental basement to the south (Rabinowitz \& LaBrecque 1979).

The nature of the basement beneath the central and southern parts of the Falkland Plateau Basin has been more open to debate. Ludwig (1983) interpreted the basin to be floored by oceanic crust, but noted that this was based on a velocity structure defined by only a few sonobuoy profiles. No refracted arrivals from the upper mantle were detected, but wide-angle reflections on Line 139 were interpreted to indicate that the Moho lies at a depth of $12 \mathrm{~km}$ beneath 5-6 km of crystalline crust, with lower crustal and upper mantle velocities of 6.6 $\mathrm{km} / \mathrm{s}$ and $7.8 \mathrm{~km} / \mathrm{s}$ respectively (Ludwig, 1983). This was supported by a gravity model presented by Barker (1999), who observed that the presence of oceanic basement is compatible with, if not directly indicative of, rotation of an independent Falkland Islands block. Isostatic considerations led Lorenzo \& Mutter (1988) to conclude that the crust beneath the Falkland Plateau Basin was around 11-12 km thick, and was either thicker-thannormal oceanic crust or stretched continental crust. Barker (1999) identified linear, NEtrending magnetic anomalies about $100 \mathrm{~km}$ ESE of the Falkland Islands which he interpreted as the expression of seaward-dipping reflectors (SDRs) at a volcanic rifted continental margin. Lorenzo \& Mutter (1988) identified possible SDRs on the eastern side of the basin (on Line 143 about $100 \mathrm{~km}$ south of the intersection with line 139), and also noted volcanic edifices which suggest melt generation at the time the basin was formed.

\section{Regional 3D modelling}

\section{Method}

A 3D model for the structure of the Falkland Plateau region has been constructed using methods described by Kimbell et al. (2004). In outline, this involves building an isostatically compensated model of lithospheric structure, calculating the associated free-air gravity anomaly and then modifying the model geometry to improve the fit with the observed gravity field. The primary inputs were:

(i) The topography of the region (Fig. 1a), based on the grid of Smith \& Sandwell (1997);

(ii) The age of ocean crust (Fig. 1b), based on the grid of Müller et al. (1997);

(iii) The free-air gravity anomaly (Fig. 1c) derived from satellite altimetry (Sandwell \& Smith 1997; Version 9.1 used for this study);

(iv) An initial compilation of sediment thickness (Fig. 2a), based on the sources described previously.

The use of a bathymetric model that was itself derived from gravity data requires justification. The method of Smith and Sandwell (1997) constrains their model to honour the control provided by depth soundings from marine surveys, and the database they employed included a particularly dense coverage of such soundings in this region. This has resulted in bathymetry that is well-constrained, at least at intermediate and longer wavelengths, and which shows little evidence of line-related noise. Although Smith and Sandwell (1997) adapted the gravity-topography transfer function to make allowance for factors such as sediment infilling of seafloor topography, there will undoubtedly be inaccuracies in the way shorter wavelength gravity variations between the survey lines are partitioned between bathymetric and bedrock causes. For this reason, the shortest wavelength features in the model presented here (which are ascribed to variations in cover sequence thickness) should 
be regarded with caution. The discussion in this paper only addresses features of longer wavelength, which are not susceptible to such ambiguity.

The lack of deep wells over much of the region means that there is little direct information on the density of the sedimentary cover rocks. On the basis of stratigraphic inferences (Richards et al. 1996) and limited density log data from the North Falkland Basin, the shale compaction curve of Sclater \& Christie (1980) was used to model the density of the cover sequence, and predicted values ranging between 1.66 and $2.70 \mathrm{Mg} / \mathrm{m}^{3}$ depending on the depth of burial. The crystalline crust (both continental and oceanic) was assumed to have an average density of $2.85 \mathrm{Mg} / \mathrm{m}^{3}$, and was split at its mid-point into upper and lower crust with densities of 2.75 $\mathrm{Mg} / \mathrm{m}^{3}$ and $2.95 \mathrm{Mg} / \mathrm{m}^{3}$ respectively.

A density model for the upper mantle was incorporated which allowed for variations in its temperature. Temperatures in oceanic areas were calculated using a cooling plate model assuming the ocean ages shown in Fig. 1b. The cooling half-space model, as employed by Kimbell et al. (2004), was not considered appropriate because the oceanic lithosphere of the Argentine Basin is old enough for its thermal decay to be influenced by the supply of heat at the base of the plate as a result of small-scale convection (Parsons \& Sclater 1977; Parsons \& McKenzie 1978). A continental geotherm based on a surface heat flow of $60 \mathrm{~mW} / \mathrm{m}^{2}$ was assumed elsewhere. This is compatible with the heat flow observed at DSDP Site 511, which lies about $11 \mathrm{~km}$ south-west of Site 330 on the Falkland Plateau (Langseth \& Ludwig 1983). Temperatures between the oceanic and continental regimes were ramped across a $100 \mathrm{~km}$ wide zone centred at the assumed continent-ocean boundary. Two-dimensional thermal modelling suggests that this is a reasonable assumption in areas of younger ocean crust and that thermal contrasts where the ocean crust is older have decayed to such an extent that the width of this ramp is not critical. In order to simulate the transition from conductive to convective heat transfer at the base of the lithosphere, this transition was approximated by the $1100^{\circ} \mathrm{C}$ isotherm (Kimbell et al. 2004), with isothermal conditions maintained between this level and the base of the model at $125 \mathrm{~km}$. When the effects of temperature and overburden stress were combined, the mantle density model predicted values ranging between 3.24 and $3.33 \mathrm{Mg} / \mathrm{m}^{3}$.

The sedimentary sequence, crystalline crust and upper mantle were assembled in an isostatic model in which the depth to the crust-mantle boundary was adjusted to equalise the load at a compensation depth of $125 \mathrm{~km}$. This boundary is assumed to be equivalent to the seismic Moho in the discussion presented here. An estimate is required for the Moho 'reference depth', which is defined as its depth beneath continental crust which has an upper surface at the topographic datum, no cover rocks, a zero gravity anomaly and mantle temperatures defined by the standard continental geotherm. The reference depth cannot be resolved from the gravity data alone, and was set at $36 \mathrm{~km}$ as a result of comparisons with seismic data (see below).

The gravity field over the complete model was then calculated using wavenumber domain routines (Parker 1972; Dabek \& Williamson 1999), and selected model interfaces were adjusted, using the method of Oldenburg (1974), to reduce the mismatch between observed and calculated anomalies. These routines are based on a flat-earth assumption but the distortion this introduces when compared to a curved-earth model is judged to be within acceptable limits (Kimbell et al. 2004). The optimisation was conducted in several stages. Firstly, a smoothing filter was applied to remove the shortest wavelengths from the isostatic Moho and then its geometry was adjusted to improve the replication of longer wavelength gravity anomalies. The thickness of the sedimentary sequence was then adjusted to reduce shorter wavelength residual anomalies. The model density structure was modified to allow 
for these geometrical changes and further iterations of the Moho and base sediments interfaces were used for 'fine-tuning'.

\section{Results}

The thickness of the sedimentary layer in the optimised model is shown in Fig. $2 b$, and the thickness of the crystalline crust and depth to Moho are shown in Figs. 3a and $3 \mathrm{~b}$ respectively. The calculated gravity field over the model (Figs. 4a) provides a close match to the observations (Fig. 1c). The largest residual anomalies occur across the southern edge of the Falkland Plateau (Fig. 4b), although even here they generally amount to less than about $10 \%$ of the observed anomaly variation. A measure of how much the model has departed from local isostatic equilibrium is provided by the load anomaly calculated at the original compensation depth (Fig. 5).

There are several sources of uncertainty in this modelling that need to be taken into account when assessing the results (Kimbell et al. 2004). The final model geometry is strongly influenced by the initial assumptions about sediment thickness and the details of the optimisation sequence. Because the Moho was optimised initially and was allowed to respond to gravity effects with wavelengths down to about $100 \mathrm{~km}$, it is inevitable that the optimised model for the sedimentary sequence (Fig. 2b) will have a similar overall form to the starting model (Fig. 2a). The consequence of this is that inaccuracies in the longer wavelength components of the initial sedimentary model will propagate into the final version. There is evidence of instability in the optimisation process on the southern margin of the Falkland Plateau, particularly between $45^{\circ} \mathrm{W}$ and $50^{\circ} \mathrm{W}$, where a zone of very thin crystalline crust (Fig. 3) appears to be an artefact which is compensated by an unlikely subsidiary thickening of the sedimentary section. This arises because of inaccuracy in partitioning the accommodation of residual gravity anomalies between the base sediment and Moho interfaces.

A major assumption is that the average density of the crystalline crust is constant throughout the area. Departures from this assumption (e.g. because of igneous intrusions) are effectively absorbed in variations in the thickness of the crystalline crust and the sedimentary layer. The adoption of the same value $\left(2.85 \mathrm{Mg} / \mathrm{m}^{3}\right)$ for crystalline continental and oceanic crust receives some support from the average oceanic density estimate of $2.86 \mathrm{Mg} / \mathrm{m}^{3}$ by Carlson and Herrick (1990). The oceanic crust may have a higher average density, however, particularly where layer 3 is thickened as a result of enhanced oceanic crustal production (White \& McKenzie 1989; Mutter \& Mutter 1993).

Another source of uncertainty is in upper mantle density variations due, for example, to different degrees of mantle depletion or to thermal contrasts not simulated in the simple temperature model adopted. There may also be deeper-seated mantle effects that introduce very long wavelength variations in the gravity field that are not properly accounted for.

\section{Analysis of the modelling results}

\section{Comparison with deep seismic data}

A section across the 3D model along line 144 (Fig. 6) illustrates the predicted variations in crustal thickness from north to south across the Falkland Plateau. The Moho lies at a similar depth (about $12 \mathrm{~km}$ ) beneath the Argentine Basin to the north and the Scotia Sea to the south, but the latter has thicker crystalline crust. Beneath the plateau, the Moho depth decreases from 25-30 km beneath the Falkland Escarpment and Burdwood Bank to around $20 \mathrm{~km}$ beneath the Falkland Plateau Basin. The Moho was not detected seismically on this line, but the interpretation of Ludwig (1983) does include a relatively high crustal velocity of $7.1 \mathrm{~km} / \mathrm{s}$ 
at shallow depth from a single sounding at about $650 \mathrm{~km}$. The modelled sedimentary thickness is in reasonable agreement with the seismic refraction interpretation of Ludwig (1983).

An east-west section through the model along line 139 (Fig. 7) indicates that the Moho lies at a depth of more than $30 \mathrm{~km}$ beneath the Falkland Platform, about $20 \mathrm{~km}$ beneath the Falkland Plateau Basin, and about $25 \mathrm{~km}$ beneath Maurice Ewing Bank. There is a major difference between this interpretation and previous identification of the seismic Moho at a depth of 12 $\mathrm{km}$ beneath the basin (Fig. 7; Ludwig 1983). Barker (1999) generated a 2D gravity model which was much closer to the seismic interpretation, and achieved this by assuming a much shallower (c. $24 \mathrm{~km})$ Moho beneath the Falkland Platform. The key difference between our gravity model and that of Barker (1999) thus appears to be the reference depth assumed for the Moho.

Comparison of the model Moho with a range of published seismic interpretations (Fig. 8) illustrates a good match with the seismic evidence at sites in the Argentine Basin and Scotia Sea, but there are discrepancies elsewhere (labelled a-e in Figs. 3 and 8). In addition to the mismatch discussed above ('a' in Figs. 3 and 8), the model Moho is substantially deeper than the seismic Moho at locations b-d near South Georgia (Ewing et al. 1971) and also just south of the Falkland Islands (e in Figs. 3 and 8; Ludwig et al. 1968). There is no systematic relationship between the average crustal velocity and the degree of mismatch in these comparisons, so it appears unlikely that the discrepancies are due to lateral crustal density variations not accounted for in the modelling. Some of the seismic Moho depths are open to doubt, because of limitations in the data from these early surveys. For example, the two determinations by Ludwig et al. (1968) lie at either end of the same traverse and are described by the authors as very tentative, as they are based on only a few Moho arrivals; the match with the 3D model is good in one case and poor in the other (e in Figs. 3 and 8). Mismatch $b$, to the north-west of South Georgia, also lies adjacent to a Moho determination that is similar to the modelled depth (Ewing et al. 1971).

It is possible that some of the mismatches arise because the seismic interface used in the comparison lies within, rather than at the base of, the crust. For example, the interpreted upper-mantle velocity of 7.5-7.6 km/s at sites c and d (Figs. 3 and 8) south-west of South Georgia (Ewing et al. 1971) could be indicative of high-velocity lower crust rather than upper mantle.

\section{Insights into lithospheric strength}

The load anomalies derived from the 3D model (Figs. 5, 6 and 7) provide insights into the strength and flexure of the lithosphere, in particular across the southern margin of the Falkland Plateau. The pattern here is characterised by a load anomaly high extending from Burdwood Bank along the North Scotia Ridge to South Georgia and a parallel low which coincides with the Falkland Trough. These features can be correlated with the thrusting of the Scotia Plate across the southern edge of the South American Plate. The overthrust Burdwood Bank and the North Scotia Ridge are supported at a relatively high level, generating a positive anomaly, while the southern edge of the Falkland Plateau is flexed downwards, generating a negative anomaly. This high-low pattern is well resolved in the load anomaly profile along line 144 (Fig. 6), with a particularly clear signature of downward flexure between $600 \mathrm{~km}$ and $740 \mathrm{~km}$.

It is possible to estimate the strength of the lithosphere from its deflection under load by reference to an elastic plate model (Sandwell \& Schubert 1992; Watts 2001; Bry et al. 2004). In Fig. 9, three profiles across the southern part of the Falkland Plateau are compared with a 
series of theoretical curves for plates with different effective elastic thicknesses $\left(T_{e}\right)$. It has been assumed that the medium above the plate is seawater (density $1.03 \mathrm{Mg} / \mathrm{m}^{3}$ ) and the medium below is mantle (density $3.3 \mathrm{Mg} / \mathrm{m}^{3}$ ), and the flexure has been displayed as load anomalies. Two end-members are illustrated in each case - one in which a load is applied to the end of a broken plate and the other in which it is applied to a continuous plate. Between these are a range of solutions representing different degrees of mechanical coupling. These profiles provide evidence of lateral changes in the strength of the lithosphere (Figs. 5 and 9). An elastic thickness of about $5 \mathrm{~km}$ is estimated on profile I, which crosses the South Falkland Basin north of Burdwood Bank. Stronger lithosphere, with an elastic thickness of $15-20 \mathrm{~km}$, is indicated on line II across the south-western part of the Falkland Plateau Basin, while a profile south of the DSDP site on Maurice Ewing Bank indicates a value of around $10 \mathrm{~km}$. These results agree with those of Bry et al. (2004), who estimated elastic thicknesses in the range $5-20 \mathrm{~km}$ from inverse modelling of gravity and bathymetric profiles and also identified the eastward increase in the strength in the South Falkland Basin. This change in strength can be seen qualitatively in variations in the width of the load anomaly low along the southern side of the Falkland Plateau (Fig. 5).

A north-east-trending load anomaly high which coincides with the gravity high about $100 \mathrm{~km}$ east-south-east of the Falkland Islands can be correlated with an area of thick sediment accumulation (Figs. 5, 1b and 2). This suggests that the anomaly may arise, at least in part, because the sediments are supported at a relatively high level by the strength of the lithosphere. There is also evidence of positive load anomalies associated with the North Falkland Basin and the thick sediments accumulated on the Argentinian margin further to the north.

The northern flank of the Falkland Plateau is characterised by load anomalies that are generally positive to the north of the Falkland Escarpment and negative to the south. The gradient zone between the positive and negative components correlates closely with the continent-ocean boundary defined by other methods (e.g. the magnetic edge anomaly of Rabinowitz \& LaBrecque (1979)). A likely explanation for this pattern is that, as the oceanic lithosphere to the north has cooled and subsided, mechanical coupling with the continental lithosphere to the south has led to the former being held at a relatively high level and the latter being depressed (Lorenzo \& Wessel 1997). This effect is more difficult to model quantitatively than on the southern margin of the plateau, perhaps because a variety of other factors have influenced the flexural behaviour of this margin over a longer timespan. These include flexural uplift resulting from unloading due to erosion (Basile \& Allemand 2002) and/or a component of extension along oceanward dipping faults (Clift \& Lorenzo 1999). Transient thermal uplift will have occurred as the oceanic ridge migrated along the transform margin and there may also have been permanent uplift if any igneous underplating occurred. Variations in sediment loading will also contribute to the flexural response of this margin. It also needs to be recognised that inaccuracies in the model will distort the load anomaly pattern: if a particular gravity feature is accommodated by topography on a density interface at an incorrect depth, its load contribution will be distorted.

\section{Discussion}

The 3D modelling suggests that the crystalline crust beneath the Falkland Plateau Basin is more than twice as thick (13-15 km compared with 5-6 km) than has previously been inferred from limited deep data provided by a seismic experiment (Ludwig 1983). The difference would be reduced if the crust beneath the basin has a lower average density than the oceanic crust to the north and south, but the measured seismic velocities are similar so this is considered unlikely. Even if a density difference of $0.1 \mathrm{Mg} / \mathrm{m}^{3}$ is introduced, it only 
accounts for about $2 \mathrm{~km}$ of the discrepancy. The Moho could be maintained at a relatively shallow level if the underlying mantle has an anomalously low density, either because of a thermal anomaly or a compositional effect. The thermal anomaly associated with the formation of the basin will, however, have largely decayed since extension ceased in the Late Jurassic or Early Cretaceous, and thinning of the continental crust beneath the basin will have reduced the heat generated by the radiogenic elements it contains. If depleted continental lithospheric mantle underlies the basin, its density may be lower than that of the mantle beneath the oceanic regions to the north and south, although the effect is more marked for Archaean lithosphere than for the Proterozoic lithosphere that is probable in this area (Poudjom Djomani et al. 2001). The density of the upper mantle could have been reduced by partial serpentinisation if extreme extension allowed the ingress of seawater to upper mantle levels, as has been suggested in the case of the Rockall Basin to the west of Ireland (O'Reilly et al. 1996). Relatively low temperatures are, however, required for the lower crust to deform in a brittle fashion and for a sufficient thickness of the upper mantle to lie within the stability field for serpentinite (Pérez-Gussinyé et al. 2001).

An alternative explanation is that the deepest layer detected by the previous seismic experiment was a zone of igneous underplating rather than the upper mantle. Zones at the base of the crust with high seismic velocities $(\geq 7.2 \mathrm{~km} / \mathrm{s})$ are often detected at volcanic continental margins, and have been interpreted to be due to underplating by basic igneous rocks formed during rifting when mantle temperatures are higher than normal (White \& McKenzie 1989). This process is not confined to continental margins, and can affect intracontinental areas, with the thickness of the underplated zone depending on a combination of the amount and duration of extension and the mantle temperature (Bown \& White 1995). Reconstructions indicate that the Falkland Plateau region lay at the edge of the major KarooFerrar magmatic province in the Early - Middle Jurassic (e.g. Macdonald et al. 2003), so the conditions may well have been favourable for underplating. It is this consideration that makes the hypothesis more likely than one involving serpentinisation of the upper mantle. Karoo age igneous activity in the region is demonstrated by the dykes of this age exposed on the Falkland Islands (Mussett \& Taylor 1994). Where underplating is present, the average crustal density will be higher than normal so the crustal thickness indicated by the 3D model may be an underestimate, although the effect may be offset to some extent by reduction in the density of the underlying mantle as a result of melt extraction (Kimbell et al. 2004). As suggested by Storey et al. (1999), the lithospheric weakening associated with this thermal event may have facilitated the formation and rotation of a Falkland Islands microplate during Gondwana breakup.

The Falkland Plateau probably lay adjacent to the Weddell Sea embayment (Filchner Block) before Antarctica split from Gondwana (Livermore \& Hunter 1996; Jokat et al. 2003), so it is instructive to look for parallels between the two regions. King (2000) produced a crustal profile extending across the Weddell Sea embayment from the Antarctic Peninsular to Coats Land merging the results of Kudryavtzev et al. (1987), Hübscher (1994), and Hübscher et al. (1996a 1998). This shows a deep sedimentary basin (10-12 km of sediments) overlying an approximately $20 \mathrm{~km}$ thick, three-layer crust with upper-, middle- and lower-crustal velocities of $5.4-5.7 \mathrm{~km} / \mathrm{s}, 6.5-6.6 \mathrm{~km} / \mathrm{s}$ and $7.1-7.5 \mathrm{~km} / \mathrm{s}$ respectively. Hübscher et al. $(1996 a, b)$ and King (2000) interpreted these velocities to be indicative of extended and underplated continental crust. The velocity structure is similar to that beneath the Falkland Plateau Basin, providing the possibility of a high velocity lower crust beneath the latter is accepted. King (2000) drew parallels between the extension of the Filchner Block and that in the Falkland Plateau Basin and inferred that this occurred between 184 and $175 \mathrm{Ma}$ (Early Mid Jurassic). 
In addition to the linear north-east-trending magnetic anomalies at the western margin of the Falkland Plateau Basin, the magnetic mapping of Barker (1999; his fig. 5) reveals longer wavelength $(50-100 \mathrm{~km})$ magnetic anomalies extending across the basin. There is evidence of further anomalies to the east and north-east of the area shown by Barker (1999) in magnetic data from the GEODAS marine trackline database (National Geophysical Data Center 2004), although the coverage is sparse. The scale of the anomalies indicates substantial crustal magnetisation variations, and possible sources are structures within a Mesoproterozoic basement and igneous bodies associated with later magmatism. Basement magnetic sources in southern Africa (in particular the source of the Beattie Anomaly; Harvey et al. 2001) and Antarctica may have originally been linked through the Falkland Plateau region (Jokat et al. 2003). The location of the region in relation to the Karoo-Ferrar province suggests the likelihood of later igneous activity, and this was the explanation favoured by Ferris et al. (2000) for the magnetic anomalies with similar wavelengths and amplitudes that characterise the Filchner Block (see also Golynsky et al. 2002). The northernmost of those anomalies form a belt comprising the Explora, Andenes and Orion anomalies which may represent the signatures of a volcanic margin at the edge of the Filchner Block. The Explorer and Andenes anomalies can be correlated with seaward-dipping reflectors (SDRs) (Kristofferson \& Hinz 1991; Ferris et al. 2000).

It is not clear from the magnetic evidence whether fully oceanic basement underlies the Falkland Plateau Basin. Such basement could have been generated as a result of the rotation and translation of a Falkland Islands microplate in Early-Middle Jurassic times, or subsequently, as a result of the separation of the Falkland Plateau from Antarctica (Barker 1999). However, the interpretation of linear, NE-trending magnetic anomalies on the western basin margin as SDRs by Barker (1999) is not corroborated by recent commercial seismic reflection surveys, and the apparent SDRs identified further east by Lorenzo and Mutter (1988) do not coincide with a local magnetic anomaly. Even if it exists beneath the southern part of the basin, oceanic crust is unlikely to extend to the northern Falkland Plateau, as continental basement is indicated there by tilted fault blocks and gneissic rocks in dredge hauls (Lorenzo \& Mutter 1988), and by a consistent continent-ocean magnetic anomaly just to the north of the plateau (Rabinowitz \& LaBrecque 1979), at a location which coincides with that predicted by load anomalies calculated from the present modelling (Fig. 5).

A lateral change in the properties of the Falkland Plateau is indicated by the way it has responded to the load placed on its southern side by the overriding Scotia Plate. The flexural modelling demonstrates an increase in lithospheric strength eastward from the South Falkland Basin, south of the Falkland Islands, into the south-western part of the Falkland Plateau Basin. Bry et al. (2004) correlated this change with a decrease in the density and penetration of normal faulting. The lithosphere becomes weaker again further to the east, on the south side of Maurice Ewing Bank. Corroborating evidence for the strength of the lithosphere in the southern Falkland Plateau Basin is provided by the positive gravity and load anomalies associated with sediment loading at its western margin (Figs. 1b and 5). The strength of the lithosphere is affected by the composition and proportions of the mechanically competent crust and upper mantle, and the degree of coupling between these (Burov \& Diament 1995). Yield strength increases with decreasing quartz content, so the continental crust is generally weaker than oceanic crust or lithospheric mantle. Ductile flow occurs at lower temperatures in relatively quartz-rich crustal rocks than in mantle rocks and, where the crust is sufficiently thick, the lithosphere may be weakened by decoupling of the upper crust from the upper mantle by a lower crustal ductile layer (the 'jelly sandwich' model). Where the continental crust is thinned, the lithosphere can be strengthened because of the decrease in the relatively weak, quartz-rich component and because the temperature in the lower crust may be reduced 
to the point where it no longer behaves in a ductile fashion and crust and upper mantle are coupled (Burov \& Diament 1995; Brown \& Phillips 2000). If underplating is present, it will contribute to this strength because of its relatively low quartz content. The increased strength of the lithosphere beneath the southern part of the Falkland Plateau Basin may thus be explained either by it being oceanic in origin (as suggested by Barker 1999) or by thinning and underplating of continental crust. Doubt has been cast on the 'jelly sandwich' model for continental rheology, because of diminishing evidence for earthquakes generated at upper mantle depths (Jackson, 2002). The implication is that the strength of continental lithospheric may reside solely in the seismogenic crustal layer. The estimated elastic thicknesses to the south of the Falkland Islands and Maurice Ewing Bank are less than the modelled thickness of crystalline crust at these locations, in conformity with this prediction, but the same does not apply beneath the southern Falkland Plateau Basin $\left(T_{e}=15-20 \mathrm{~km}\right.$; thickness of crystalline crust $=15 \mathrm{~km}$ ), confirming its anomalous nature.

\section{Conclusions}

A 3D model for the lithospheric structure of the Falkland Plateau region has been constructed, incorporating thermal and isostatic effects and existing sedimentary thickness data, and refining the model geometries by inversion of gravity anomalies. Such modelling provides relative rather than absolute measures of crustal thickness and is thus dependent on the control provided by available deep seismic survey data, which in this region are of an early vintage. A model which provides the best fit with the majority of seismic experiments indicates a substantially greater crustal thickness beneath the Falkland Plateau Basin than suggested by a seismic estimate at this locality, which was based on very limited data (Ludwig 1983). The difference could be due to relatively low density upper mantle beneath the basin or to the presence of high-velocity lower crust which was not penetrated by the seismic experiment. The latter explanation is preferred, and is compatible with underplating formed as the result of the development of the basin within the influence of the Karoo-Ferrar plume. Departures from local isostasy in the 3D model provide insights into flexural effects which can be used to investigate the strength of the lithosphere. Variations in the flexural response to loading by the Scotia Plate indicate that the lithosphere beneath the southern part of the Falkland Plateau Basin is stronger than that to the east and west, either because it is oceanic or because of strengthening as a result of extension and underplating of continental crust. The thicker crust to the north of the Falkland Plateau Basin is inferred to be continental, however, with coincident flexural and magnetic anomalies defining the position of the boundary between this and the oceanic basement of the Argentine Basin further north.

This paper is published with the permission of the Falkland Islands Government and the Executive Director of the British Geological Survey (NERC).

\section{References}

Barker, P.F. 1999. Evidence for a volcanic rifted margin and oceanic crustal structure for the Falkland Plateau Basin. Journal of the Geological Society, 156, 889-900.

Barker, P.F., Dalziel, I.W.D. et al. 1976. Initial Reports of the Deep Sea Drilling Project, No. 36. (Washington: US Government Printing Office.)

Basile, C. \& Allemand, P, 2002. Erosion and flexural uplift along transform faults. Geophysical Journal International, 151, 646-653. 
Bown, J.W. \& White, R.S. 1995. Finite duration rifting, melting and subsidence at continental margins. In: Banda, E., Torné, M. \& Talwani, M. (eds.) Rifted Ocean-Continent Boundaries. NATO Advanced Science Institute Series, Series C, 463, 31-54.

Brown, C.D. \& Phillips, R.J. 2000. Crust-mantle decoupling by flexure of continental lithosphere. Journal of Geophysical Research, 105, 13221-13237.

Bry, M., White, N., Singh, S., England, R. \& Trowell, C. 2004. Anatomy and formation of oblique continental collision: South Falkland basin. Tectonics, 23, TC4011.

Burov, E.B. \& Diament, M. 1995. The effective elastic thickness $\left(\mathrm{T}_{\mathrm{e}}\right)$ of continental lithosphere: What does it really mean? Journal of Geophysical Research, 100, 3905-3927.

Carlson, R.L. \& Herrick, C.N. 1990. Densities and porosities in the oceanic crust and their variations with depth and age. Journal of Geophysical Research, 95, 9153-9170.

Clift, P.D. \& Lorenzo, J.M. 1999. Flexural unloading and uplift along the Côte d'IvoireGhana Transform Margin, equatorial Atlantic. Journal of Geophysical Research, 104, 2525725274.

Curtis, M.L. \& Hyam, D.M. 1998. Late Palaeozoic to Mesozoic structural evolution of the Falkland Islands: a displaced segment of the Cape Fold Belt. Journal of the Geological Society, 155, 115-129.

Dabek, Z.K. \& Williamson, J.P. 1999. Forward and inverse wavenumber formulae for the gravity and magnetic responses of layered models. British Geological Survey Technical Report WK/99/03C.

Divins, D.L. \& Rabinowitz, P.D. 1990. Total sediment thickness map for the South Atlantic Ocean. In: Udintsev, G B (ed.) International Geological-Geophysical Atlas of the Atlantic Ocean. Intergovernmental Oceanographic Commission, Ministry of Geology of the USSR, Moscow, 126-127.

Ewing, M., Ludwig, W.J. \& Ewing, J.L. 1964. Sediment distribution in the oceans: the Argentine Basin. Journal of Geophysical Research, 69, 2003-2017.

Ewing, J.L., Ludwig, W.J., Ewing, M. \& Eittreim, S.L. 1971. Structure of the Scotia Sea and Falkland Plateau. Journal of Geophysical Research, 76, 7118-7137.

Ferris, J.K., Vaughan, A.P.M. \& Storey, B.C. 2000. Relics of a complex triple junction in the Weddell Sea embayment, Antartica. Earth and Planetary Science Letters, 178, 215-230.

Golynsky, A.V., Morris, P., Kovacs, L.C. \& Ferris, J.K. 2002. A new magnetic map of the Weddell Sea and Antarctic Peninsula. Tectonophysics, 347, 3-11.

Harvey, J.D., de Wit, M.J., Stankiewicz, J. \& Doucouré, C.M. 2001. Structural variations of the crust in the Southwestern Cape deduced from seismic receiver functions. South African Journal of Geology, 104, 231-242.

Hübscher, C. 1994. Krustenstrukturen und Verlauf des Kontinentalrandes im Weddell Meer, Antarktis. Berichte zur Polarforschung, No. 147.

Hübscher, C., Jokat, W. \& Miller, H. 1996a. Structure and origin of southern Weddell Sea crust: results and implications. In: Storey, B.C., King, E.C. \& Livermore, R.A. (eds.) Weddell Sea Tectonics and Gondwana Break-up. Geological Society, London, Special Publications, 108, 210-211

Hübscher, C., Jokat, W. \& Miller, H. 1996b. Crustal structure of the Antarctic continental margin in the eastern Weddell Sea. In: Storey, B.C., King, E.C. \& Livermore, R.A. (eds.) 
Weddell Sea Tectonics and Gondwana Break-up. Geological Society, London, Special Publications, 108, 165-174.

Hübscher, C., Jokat, W., King, E., Kudryavtzev, G. \& Leitchenkov, G. 1998. The Weddell Sea Basin between Berkner Island and Antarctic Peninsula. Terra Antarctica, 5, 195-198.

Jacobs, J., Thomas, R.J., Armstrong, R.A. \& Friedhelm, H-K. 1999. Age and thermal evolution of the Mesoproterozoic Cape Meredith Complex, West Falkland. Journal of the Geological Society, London, 156, 917-928.

Jackson, J.A. 2002. Strength of continental lithosphere: Time to abandon the jelly sandwich? GSA Today, 12, 4-10.

Jokat, W., Boebel, T., König, M. \& Meyer, U. 2003. Timing and geometry of early Gondwana breakup. Journal of Geophysical Research, 108 (B9), 2428.

Kimbell, G.S., Gatliff, R.W., Ritchie, J.D., Walker, A.S.D. \& Williamson, J.P. 2004. Regional three-dimensional modelling of the NE Atlantic margin. Basin Research, 16, 259278.

King, E.C. 2000. The crustal structure and sedimentation of the Weddell Sea embayment: implications for Gondwana reconstructions. Tectonophysics, 327, 195-212.

Kristofferson, Y. \& Hinz, K. 1991. Crustal development: Weddell Sea - Ross Sea region. In Thomson, M.R.A, Crame, J.A. \& Thomson, J.W. (eds.) Geological Evolution of Antartica. Cambridge University Press, 225-230.

Kudryavtzev, G., Smirnova, E.A., Schumilov, V.A. \& Poselov, V.A. 1987. Deep structure of the earth crust in the southern part of the Weddell Sea by data of the DSS line. In: Ivanov, V.L. \& Grikurov, G.E. (eds) Geological and Geophysical Researchin Antractica. Sevmorgeologia, Leningrad, 99-108 [in Russian].

Langseth, M.G. \& Ludwig, W.J. 1983. A heat flow measurement on the Falkland Plateau. Initial Reports of the Deep Sea Drilling Project, 71, 299-303.

Livermore, R.A. \& Hunter, R.J. 1996. Mesozoic seafloor spreading in the southern Weddell Sea. In: Storey, B.C., King, E.C. \& Livermore, R.A. (eds.) Weddell Sea Tectonics and Gondwana Break-up. Geological Society, London, Special Publications, 108, 227-241.

Lorenzo, J.M. \& Mutter, J.C. 1988. Seismic stratigraphy and tectonic evolution of the Falkland/Malvinas Plateau. Revista Brasileira de Geociências, 18, 191-200.

Lorenzo, J.M. \& Wessel, P. 1997. Flexure across a continent-ocean fracture zone: the northern Falkland/Malvinas Plateau, South Atlantic. Geo-marine Letters, 17, 110-118.

Ludwig, W.J. 1983. Geologic framework of the Falkland Plateau. Initial Reports of the Deep Sea Drilling Project, 71, 281-293.

Ludwig, W.J., Ewing, J.I. \& Ewing, M. 1968. Structure of Argentine coastal margin. Bulletin of th American Association of Petroleum Geologists, 52, 2337-2368.

Macdonald, D., Gomez-Perez, I., Franzese, J., Spalletti, L., Lawver, L., Gahagan, L., Dalziel, I., Thomas, C., Trewin, N., Hole, M. \& Paton, D. 2003. Mesozoic break-up of SW Gondwana: implications fro regional hydrocarbon potential of the southern Atlantic. Marine and Petroleum Geology, 20, 287-308.

Marshall, J.E.A. 1994. The Falkland Islands: a key element in Gondwana palaeogeography. Tectonics, 13, 499-514. 
Max, M.D., Ghidella, M., Kovacs, L., Paterlini, J.A. \& Valladares, J.A. 1999. Geology of the Argentine continental shelf and margin from aeromagnetic survey. Marine and Petroleum Geology, 16, 41-64.

Müller, R.D., Roest W.R., Royer, J.-Y., Gahagan, L.M. \& Sclater, J.G. 1997. Digital isochrons of the world's ocean floor. Journal of Geophysical Research, 102, 3211-3214.

Mussett, A.E. \& Taylor, G.K. 1994. ${ }^{40} \mathrm{Ar}-{ }^{39} \mathrm{Ar}$ ages for dykes from the Falkland Islands with implications for the break-up of southern Gondwanaland. Journal of the Geological Society, London, 151, 79-91.

Mutter, C.Z. \& Mutter, J.C. 1993. Variations in thickness of layer 3 dominate oceanic crustal structure. Earth and Planetary Science Letters, 117, 295-317.

National Geophysical Data Center, 2004. GEODAS Marine Trackline Geophysics (on DVD or CD-ROM). [See http://www.ngdc.noaa.gov/mgg/geodas/trackline.html].

Oldenburg, D.W. 1974. The inversion and interpretation of gravity anomalies. Geophysics, 39, 526-536.

O'Reilly, B.M., Hauser, F., Jacob, A.W.B. and Shannon, P.M. 1996. The lithosphere below the Rockall Trough: wide-angle seismic evidence for extensive serpentinisation. Tectonophysics, 255, 1-23.

Parker, R.L. 1972. The rapid calculation of potential anomalies. Geophysical Journal of the Royal Astronomical Society, 31, 447-455.

Parsons, B. \& Sclater, J.C. 1977. An analysis of the variation of ocean floor bathymetry and heat flow with age. Journal of Geophysical Research, 82, 803-827.

Parsons, B. \& McKenzie, D. 1978. Mantle convection and the thermal structure of the plates, Journal of Geophysical Research, 83, 4485- 4496.

Pérez-Gussinyé, M., Reston, T.J. \& Phipps Morgan, J. 2001. Serpentinization and magmatism during extension at non-volcanic margins: the effect of initial lithospheric structure. In: Wilson, R.C.L., Whitmarsh, R.B., Taylor, B. \& Froitzheim, N. (eds.) Nonvolcanic rifting of continental margins: a comparison of evidence from land and sea. Geological Society, London, Special Publications, 187. 551-576.

Poudjom Djomani, Y.H., O’Reilly, S.Y., Griffin, W.L. \& Morgan, P. 2001. The density structure of subcontinental lithosphere through time. Earth and Planetary Science Letters, 184, 605-621.

Rabinowitz, P.D. \& LaBrecque, J. 1979. The Mesozoic South Atlantic Ocean and evolution of its continental margins. Journal of Geophysical Research, 84, 5973-6002.

Richards, P.C., Gatliff, R.W., Quinn, M.F., Williamson, J.P. \& Fannin, N.G.T. 1996. The geological evolution of the Falkland Islands continental shelf. In: Storey, B.C., King, E.C. \& Livermore, R.A. (eds.) Weddell Sea Tectonics and Gondwana Break-up. Geological Society, London, Special Publications, 108, 105-128.

Sandwell, D.T. \& Schubert, G. 1992. Flexural ridges, trenches. \& outer rises around coronae on Venus. Journal of Geophysical Research - Planets, 97, 16069-16083.

Sandwell, D.T. \& Smith, W.H.F. 1997. Marine gravity anomaly from Geosat and ERS 1 satellite altimetry. Journal of Geophysical Research, 102, 10039-10054. 
Sclater, J.G. \& Christie, P.A.F. 1980. Continental stretching: an explanation of the post-midCretaceous subsidence of the central North Sea basin. Journal of Geophysical Research, 85, 3711-3739.

Smith, W.H.F. \& Sandwell, D.T. 1997. Global seafloor topography from satellite altimetry and ship depth soundings, Science, 277, 1957-1962.

Storey, B.C., Curtis, M.L., Ferris, J.K., Hunter, M.A., and Livermore, R.A. 1999. Reconstruction and break-out model for the Falkland Islands within Gondwana. Journal of African Earth Sciences, 29, 153-163.

Taylor, G.K. \& Shaw, J. 1989. The Falkland Islands: new palaeomagnetic data and their origin as a displaced terrane from southern Africa. In: Hillhouse, J W (ed.) Deep structure and past kinematics of accreted terranes. American Geophysical Union, Geophysical Monograph, 50, 59-72.

Thomas, R.J., Jacobs, J. \& Eglington, B.M. 2000. Geochemistry and isotopic evolution of the Mesoproterozoic Cape Meredith Complex, West Falkland. Geological Magazine, 137, 537553.

Trewin, N.H., Macdonald, D.I.M. \& Thomas, C.G.C. 2002. Stratigraphy and sedimentology of the Permian of the Falkland Islands: lithostratigraphic and palaeoenvironmental links with South Africa. Journal of the Geological Society, 159, 5-19.

Turic, M.A., Mainardi, E., Hogg, S. \& Stubelj, R. 1980. Malvinas Basin - offshore Argentina. Annual Offshore Technology Conference, Houston, May 1980, Paper 3912.

Wareham, C.D., Pankhurst, R.J., Thomas, R.J., Storey, B.C., Grantham, G.H., Jacobs, J. \& Eglington, B.M. 1998. $\mathrm{Pb}, \mathrm{Nd}$, and $\mathrm{Sr}$ isotope mapping of Grenville-age crustal provinces in Rodinia. Journal of Geology, 106, 647-659.

Watts, A.B. 2001. Isostasy and Flexure of the Lithosphere. Cambridge University Press.

White, R.S. \& McKenzie, D. 1989. Magmatism at rift zones: The generation of volcanic continental margins and flood basalts. Journal of Geophysical Research, 94, 7685-7729. 


\section{Figure captions}

Fig. 1. (a) Bathymetric map of the Falkland Plateau region based on data from Smith and Sandwell (1997). (b) Age of ocean crust based on data from Müller et al. (1997). There are alternative interpretations for the location of the continent-ocean boundary on the west side of the Argentine Basin (e.g. Max et al., 1999), although this has little impact on the modelling discussed here. (c) Free-air gravity anomalies derived from satellite altimetry (Sandwell \& Smith, 1997). The image employs an equal-area colour scale and illumination from the north.

Fig. 2. (a) Initial sediment thickness estimate based on a variety of sources (see text). (b) sediment thickness in the optimised 3D model. Contours are at $1 \mathrm{~km}$ intervals in both maps.

Fig. 3. (a) Thickness of crystalline crust in the optimised $3 \mathrm{D}$ model (contours at $5 \mathrm{~km}$ intervals) (b) depth to Moho in the optimised 3D model (contours at $2 \mathrm{~km}$ intervals). Symbols indicate locations where a possible Moho has been identified in seismic experiments; selected locations are labelled (a-e) for cross-reference with Fig. 8 and discussion in the text.

Fig. 4. (a) Calculated free-air gravity anomalies over the optimised $3 \mathrm{D}$ model. Imaging parameters are identical to those used for the observed field shown in Fig. 1c. (b) Residual free-air gravity anomalies over the optimised model.

Fig. 5. Load anomalies predicted by the 3D optimised model (departures from the reference value at the base of the model at $125 \mathrm{~km}$ ). Contours are at $10 \mathrm{MPa}$ intervals. Green lines show locations of profiles I-III in Fig. 9.

Fig. 6. Section through the 3D model along airgun-sonobuoy profile 144 compared with the seismic interpretation by Ludwig (1983). For line location see Fig. 1a.

Fig. 7. Section through the 3D model along airgun-sonobuoy profile 139 compared with the seismic interpretation by Ludwig (1983). For line location see Fig. 1a.

Fig. 8. Comparison of depth to Moho in the 3D model with available seismic interpretation. Locations shown in Figs. 3a and 3b; the largest departures are labelled (a-e) to aid comparison with these figures.

Fig. 9. Load anomaly profiles from the southern edge of the Falkland Plateau compared with theoretical curves for broken and continuous flexed plates with different effective elastic thicknesses $\left(\mathrm{T}_{\mathrm{e}}\right)$. Profile locations are shown in Fig. 5. 

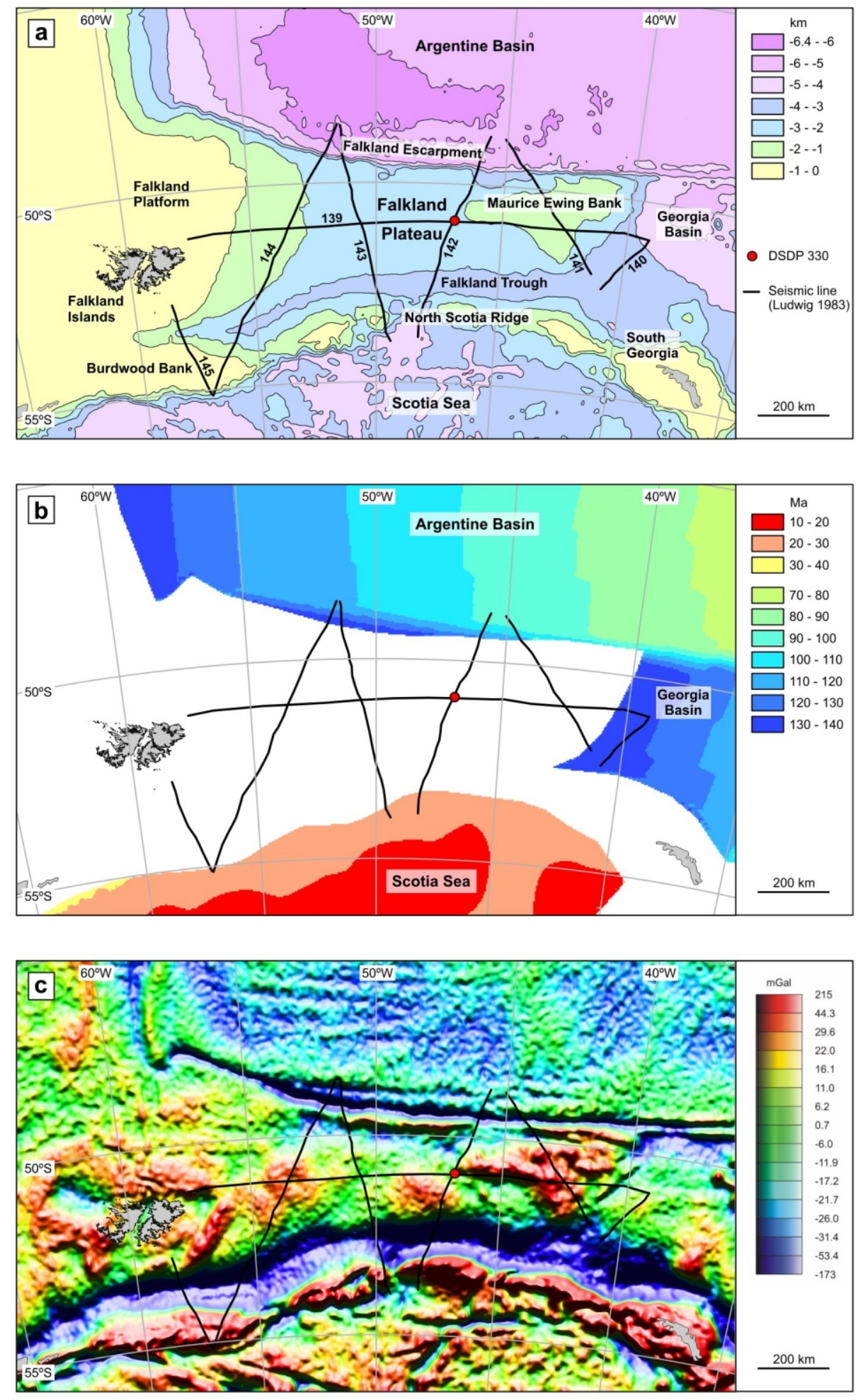

Fig. 1 

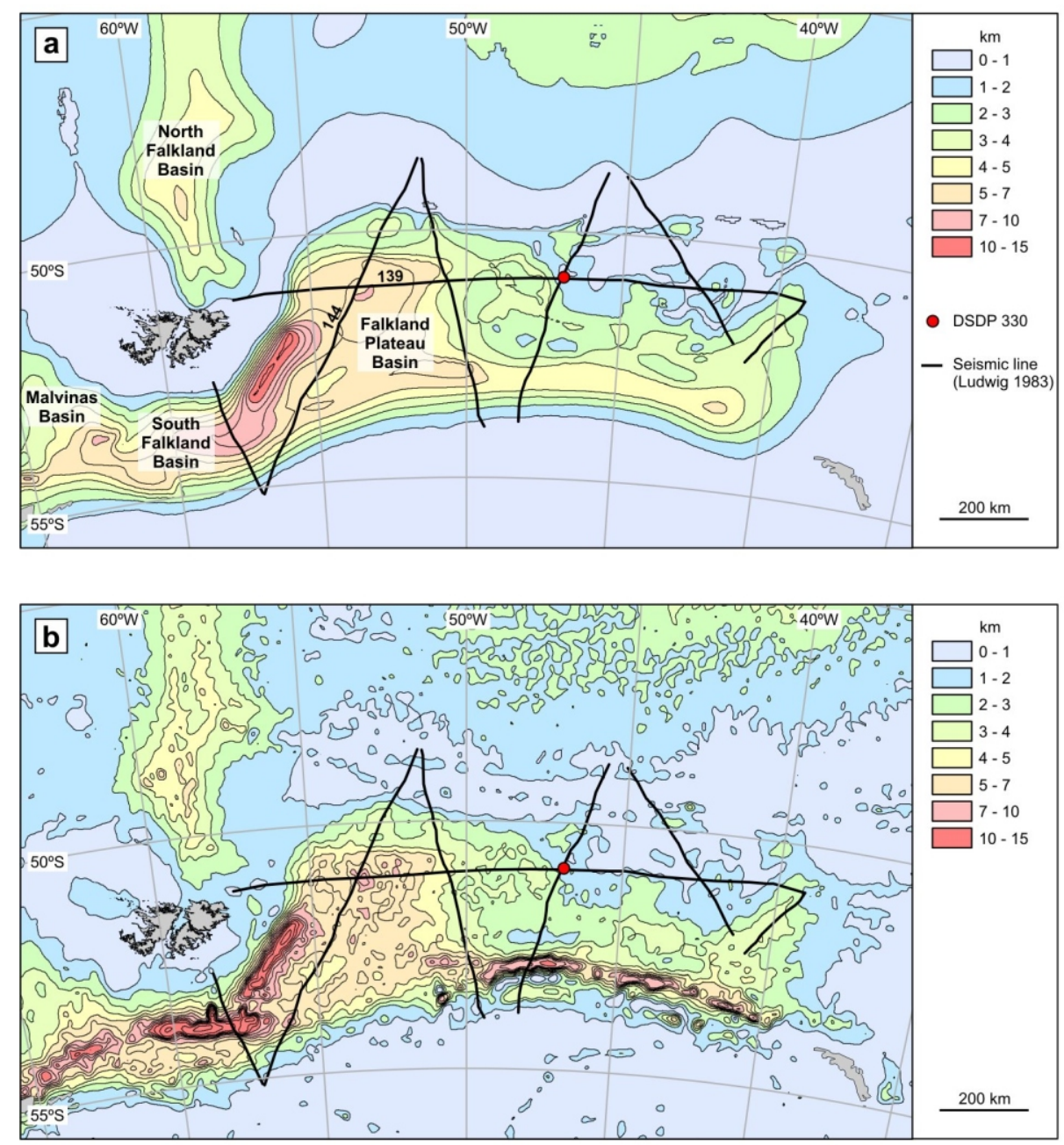

Fig. 2 

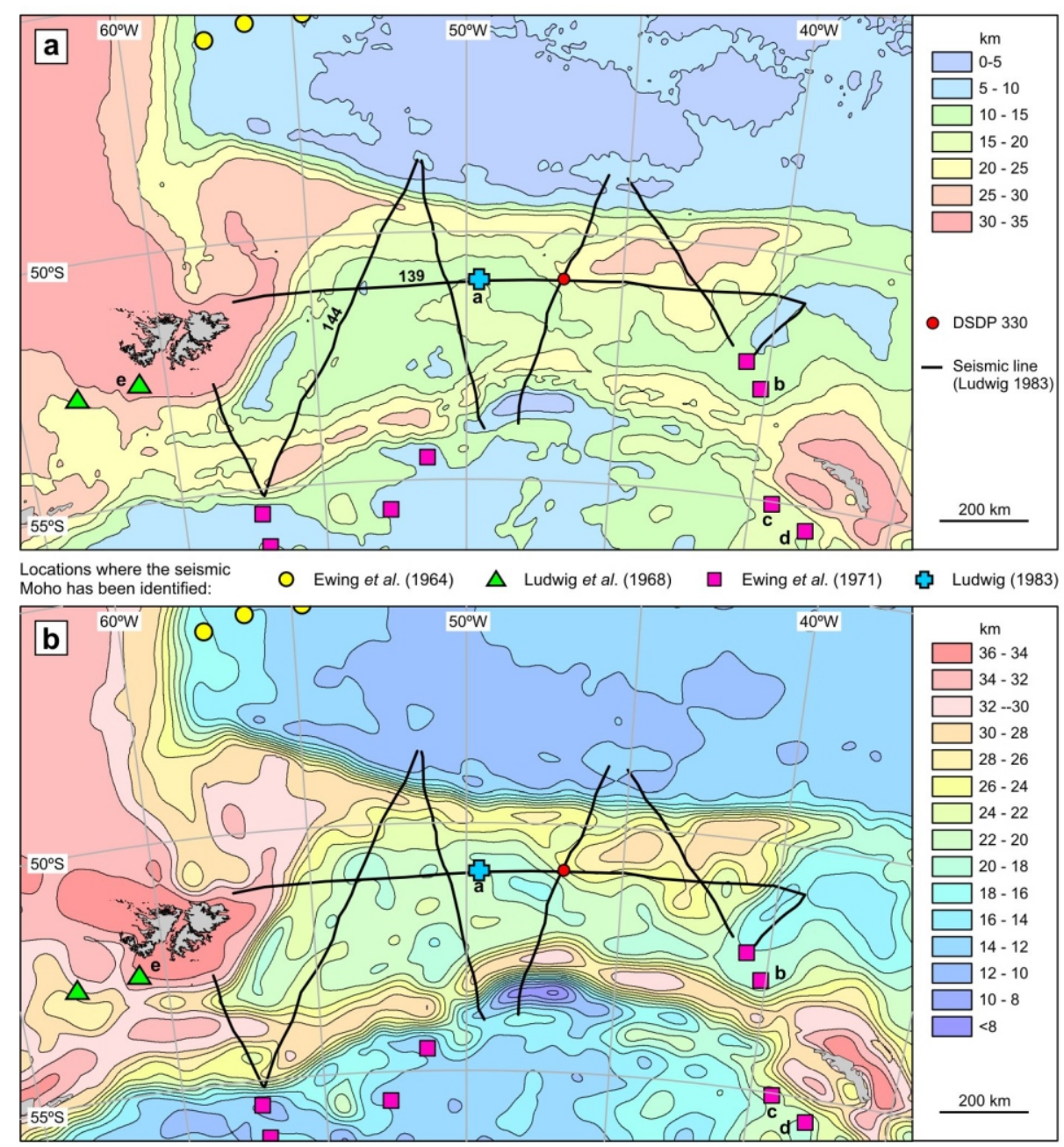

Fig. 3 

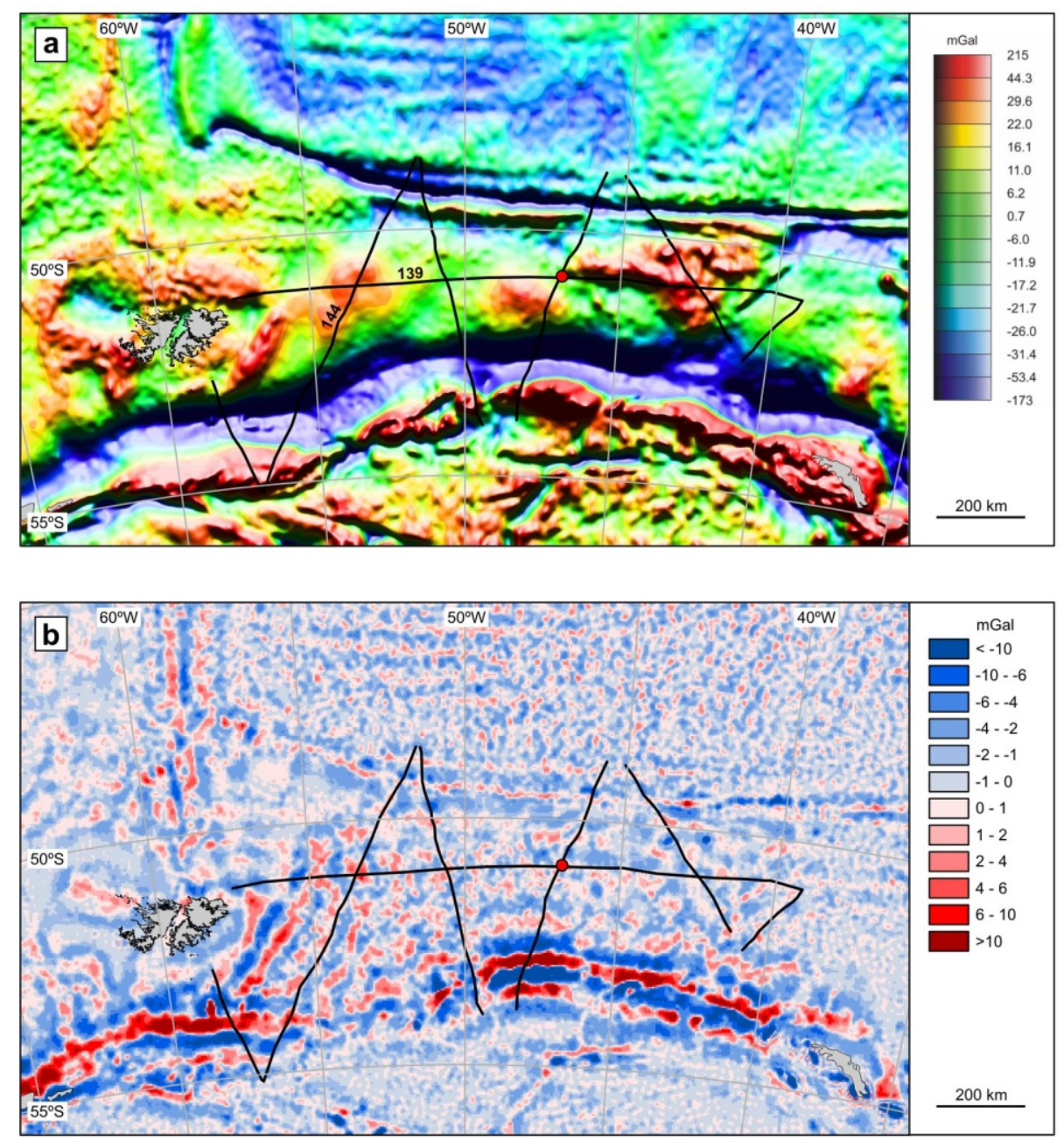

Fig. 4 


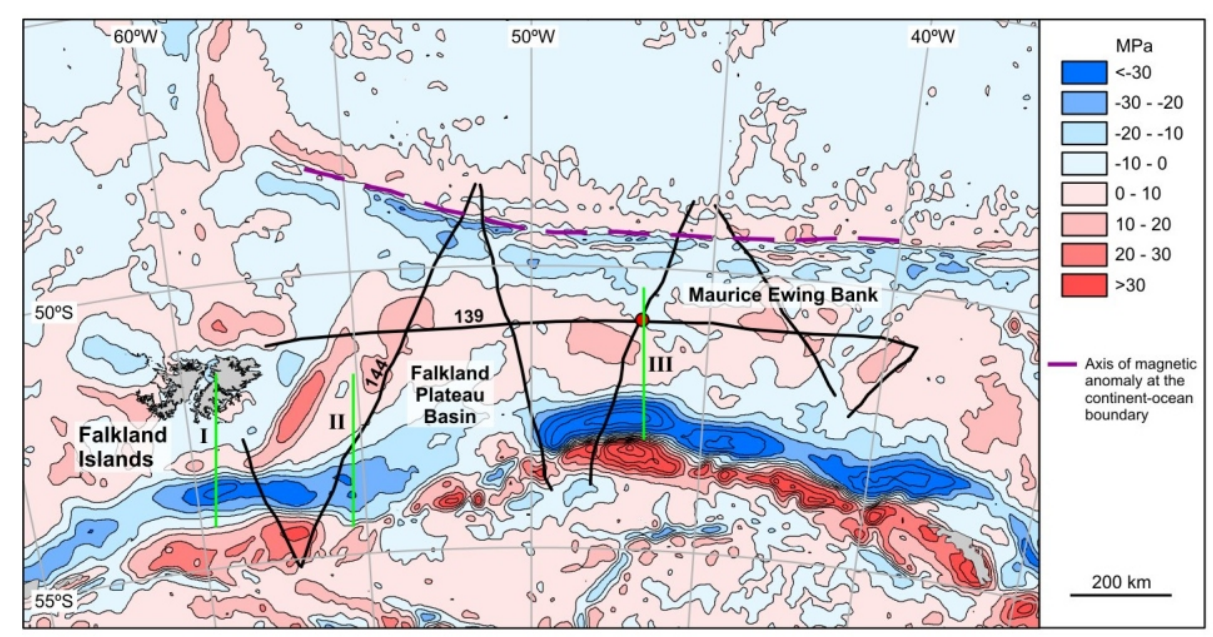

Fig. 5 

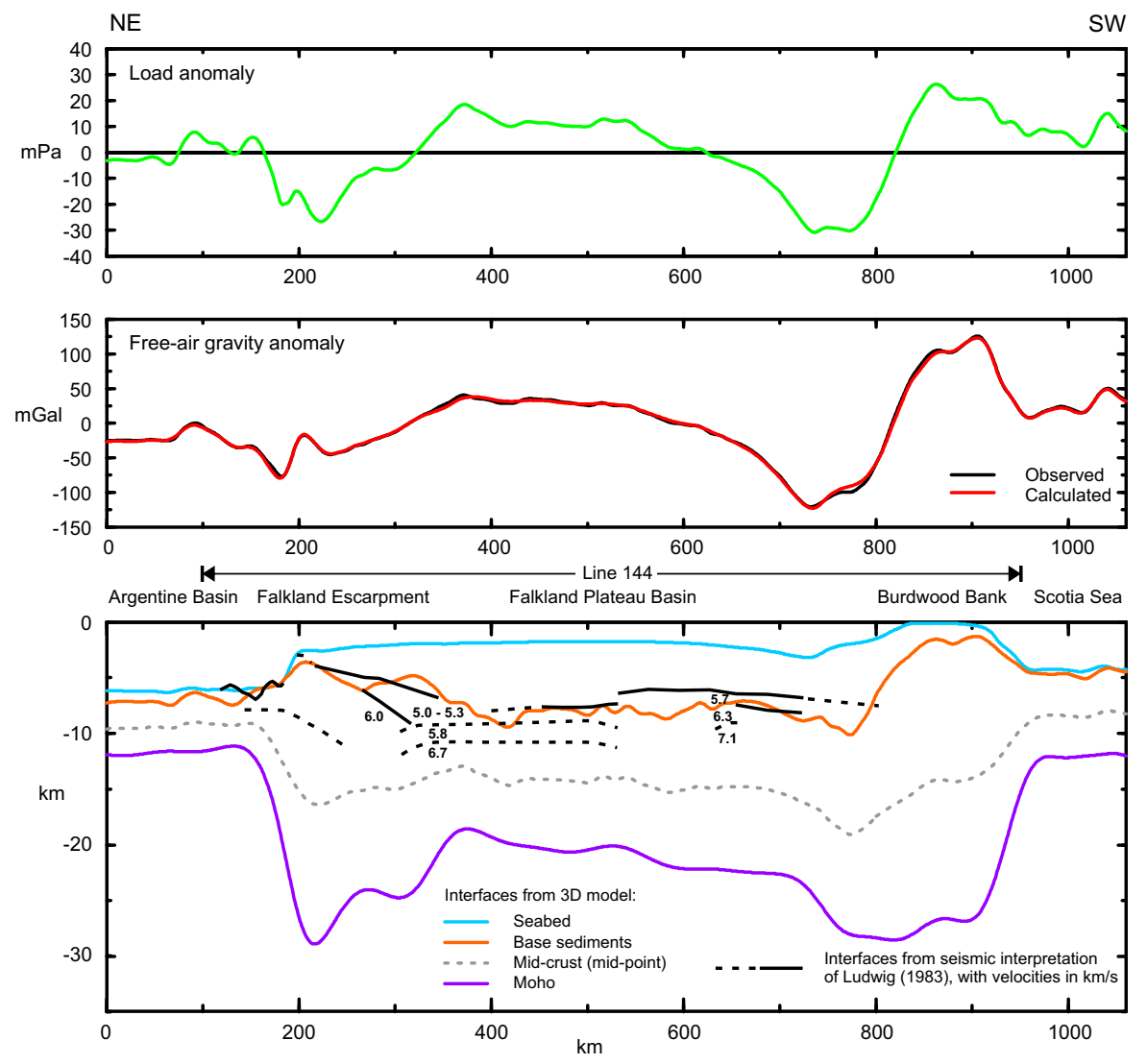

Fig. 6 

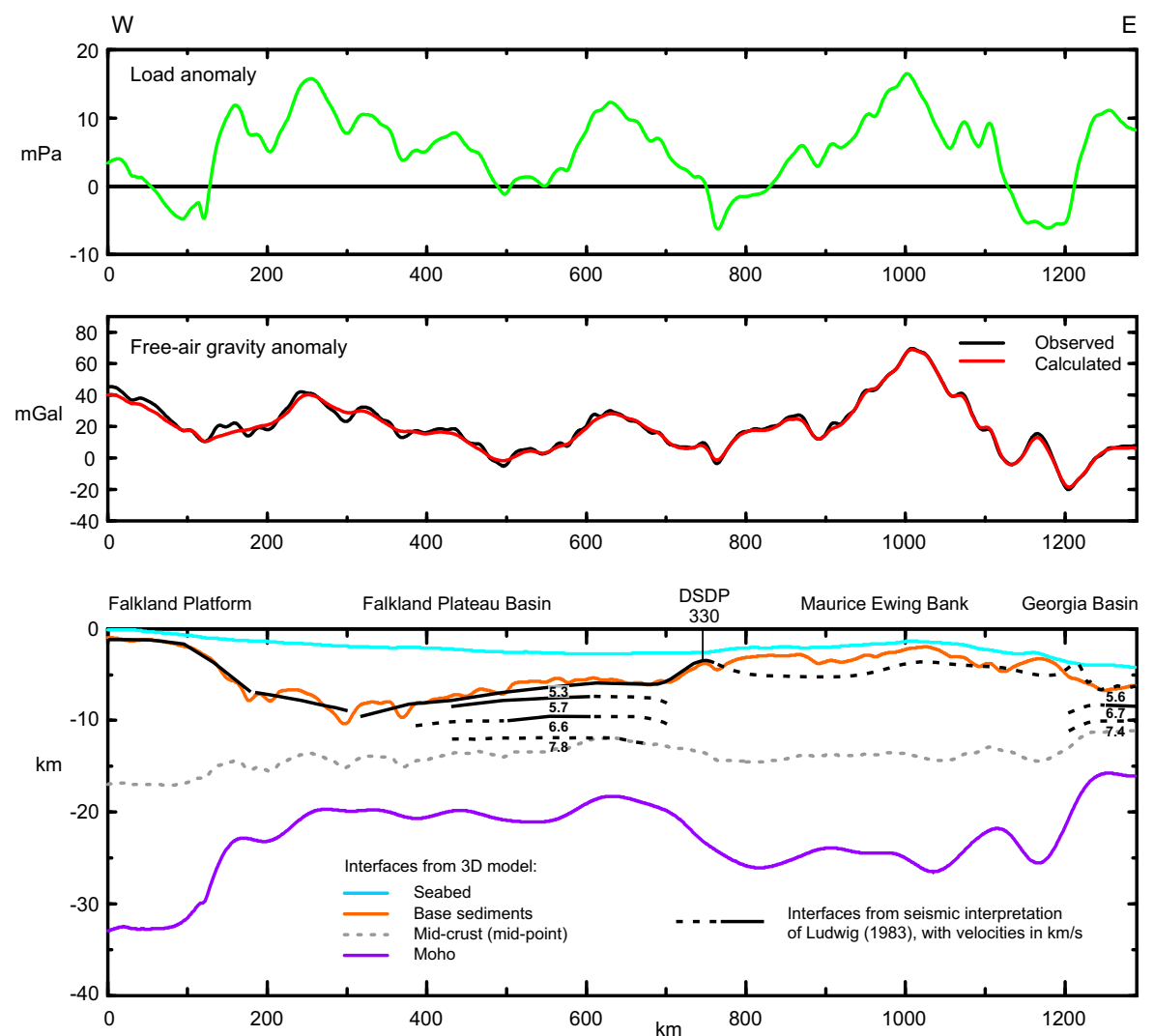

Fig. 7 


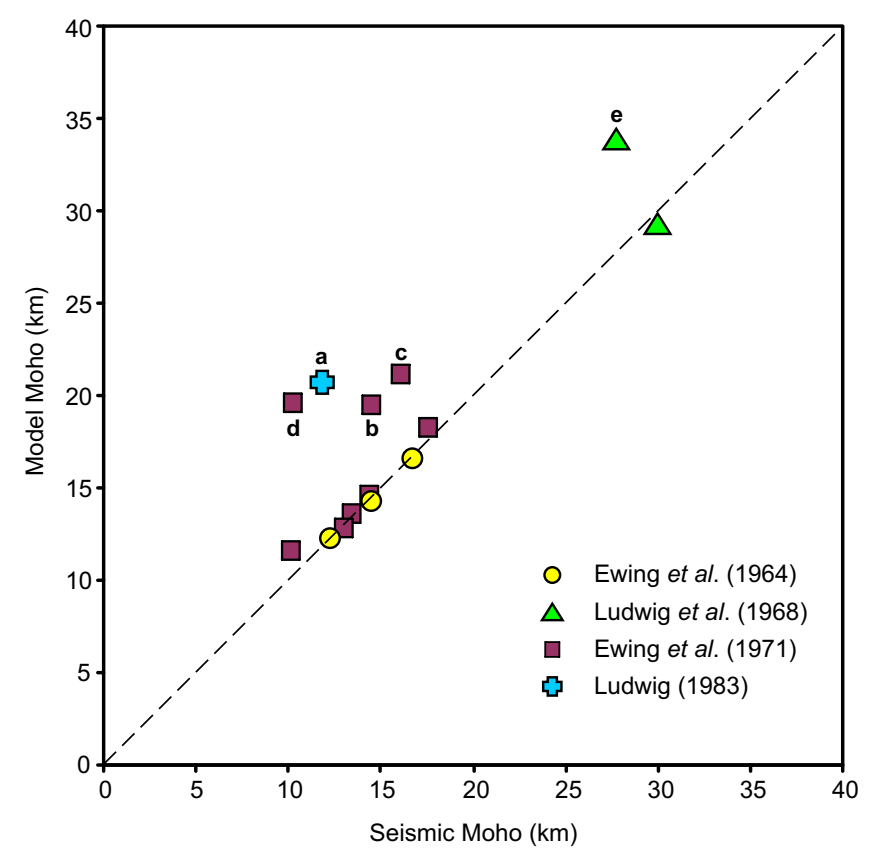

Fig. 8 

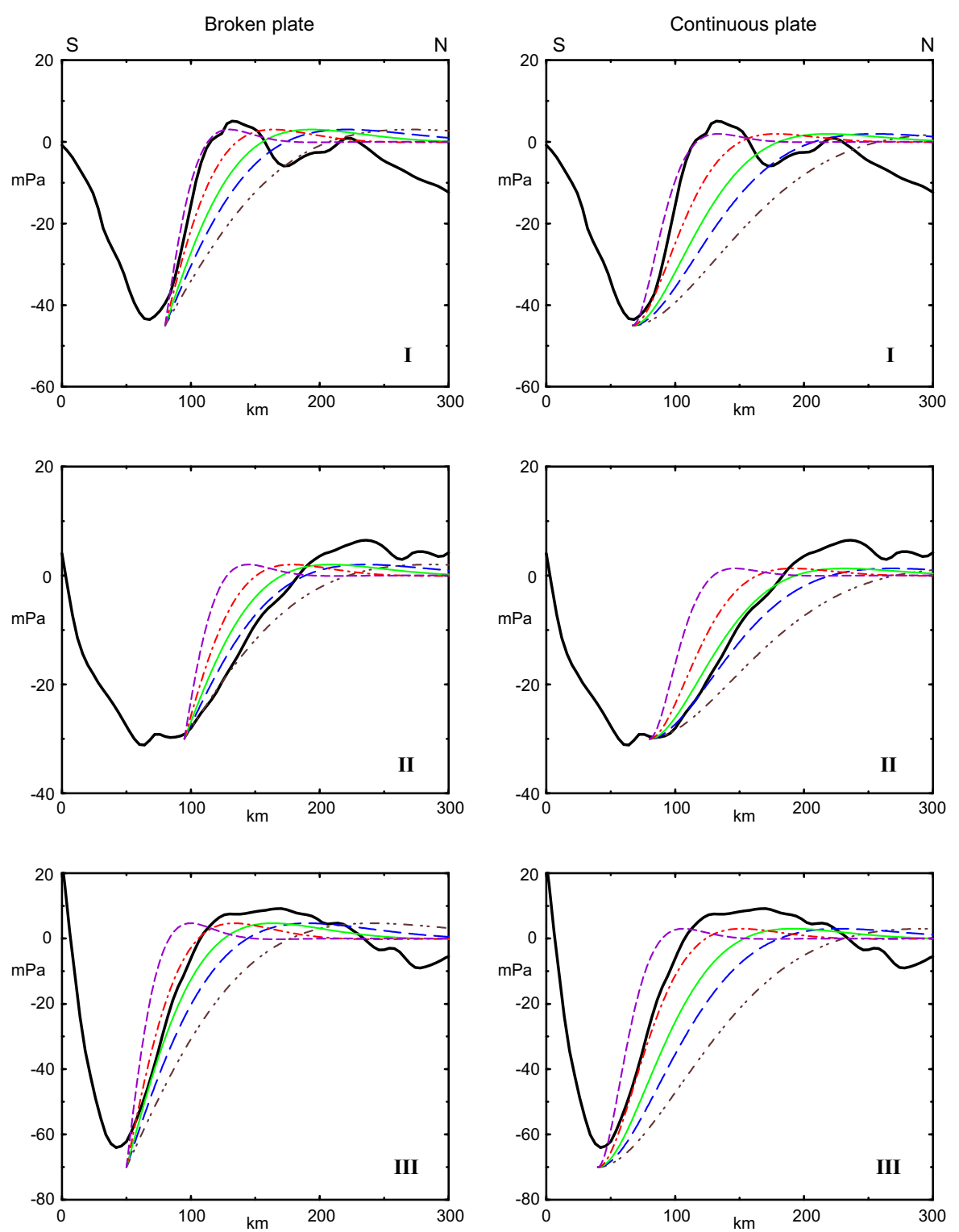

- From 3D model $\quad--\mathrm{T}_{\mathrm{e}}=5 \quad-\cdots \mathrm{T}_{\mathrm{e}}=10 \quad-\mathrm{T}_{\mathrm{e}}=15 \quad--\mathrm{T}_{\mathrm{e}}=20 \quad-\cdots-\mathrm{T}_{\mathrm{e}}=30$

Fig. 9 